\title{
Hypothalamic Non-AgRP, Non-POMC GABAergic Neurons Are Required for Postweaning Feeding and NPY Hyperphagia
}

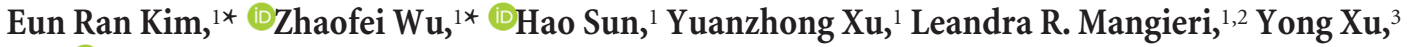 \\ and (Dingchun Tong ${ }^{1,2}$ \\ ${ }^{1}$ Brown Foundation Institute of Molecular Medicine and ${ }^{2}$ Graduate Program in Neuroscience of Graduate School of Biological Sciences, the University of \\ Texas Medical School at Houston, Houston, Texas 77030, and ${ }^{3}$ Children's Nutrition Research Center, Department of Pediatrics, Baylor College of Medicine, \\ Houston, Texas 77030
}

The hypothalamus is critical for feeding and body weight regulation. Prevailing studies focus on hypothalamic neurons that are defined by selectively expressing transcription factors or neuropeptides including those expressing proopiomelanocortin (POMC) and agoutirelated peptides (AgRP). The Cre expression driven by the pancreas-duodenum homeobox 1 promoter is abundant in several hypothalamic nuclei but not in AgRP or POMC neurons. Using this line, we generated mice with disruption of GABA release from a major subset of non-POMC, non-AgRP GABAergic neurons in the hypothalamus. These mice exhibited a reduction in postweaning feeding and growth, and disrupted hyperphagic responses to NPY. Disruption of GABA release severely diminished GABAergic input to the paraventricular hypothalamic nucleus (PVH). Furthermore, disruption of GABA-A receptor function in the PVH also reduced postweaning feeding and blunted NPY-induced hyperphagia. Given the limited knowledge on postweaning feeding, our results are significant in identifying GABA release from a major subset of less appreciated hypothalamic neurons as a key mediator for postweaning feeding and NPY hyperphagia, and the PVH as one major downstream site that contributes significantly to the GABA action.

Key words: AgRP; feeding; GABA; NPY; Pdx1-Cre; PVH

\section{Significance Statement}

Prevalent studies on feeding in the hypothalamus focus on well characterized, selective groups neurons [e.g., proopiomelanocortin (POMC) and agouti-related peptide (AgRP) neurons], and as a result, the role of the majority of other hypothalamic neurons is largely neglected. Here, we demonstrated an important role for GABAergic projections from non-POMC non-AgRP neurons to the paraventricular hypothalamic nucleus in promoting postweaning (mainly nocturnal) feeding and mediating NPY-induced hyperphagia. Thus, these results signify an importance to study those yet to be defined hypothalamic neurons in the regulation of energy balance and reveal a neural basis for postweaning (nocturnal) feeding and NPY-mediated hyperphagia.

\section{Introduction}

Prevailing studies on brain control of feeding focus on neurons that are defined by a selective expression of either transcription factors or

\footnotetext{
Received March 22, 2015; revised June 16, 2015; accepted June 16, 2015

Author contributions: E.R.K., Z.W., and Q.T. designed research; E.R.K., Z.W., H.S., Yuanzhong Xu, L.R.M., and Q.T. performed research; Yong Xu and Q.T. contributed unpublished reagents/analytic tools; E.R.K., Z.W., H.S., and Q.T. analyzed data; E.R.K., L.R.M., and Q.T. wrote the paper.

This work was supported by National Institutes of Health (NIH) R01DK092605, Grant-in-Aid Award from American Heart Association, and Basic Research Award from American Diabetes Award (to Q.T.) and NIH R01DK093587 (to Yong X.). Q.T. is the holder of Becker Family Foundation Professorship and Welch Research Scholar of the University of Texas Medical School at Houston.

*E.R.K. and Z.W. contributed equally to this work.

The authors declare no competing interests.

Correspondence should be addressed to Qingchun Tong, Brown Foundation Institute of Molecular Medicine, University of Texas Medical School at Houston, Houston, TX 77030. E-mail: qingchun.tong@uth.tmc.edu.

DOI:10.1523/JNEUROSCI.1110-15.2015

Copyright $\odot 2015$ the authors $\quad 0270-6474 / 15 / 3510440-11 \$ 15.00 / 0$
}

neuropeptides (Liu et al., 2012; Morton et al., 2014). As a result, the function of those neurons that cannot be defined by known transcription factors or neuropeptides is much less appreciated. Accumulating data suggest that these yet to be defined neurons are important for feeding and body weight regulation. Deletion of leptin receptors (LepRs) in GABAergic neurons leads to obesity similar to that of $d b / d b$ mice (Vong et al., 2011). In contrast, deletion of LepR in each of the known, well studied neuronal groups, including POMC and AgRP neurons, only leads to mild obesity (Balthasar et al., 2004; van de Wall et al., 2008). Although deletion of LepRs in GABAergic neurons occurs in regions beyond the hypothalamus, these results suggest an importance for non-POMC, non-AgRP neurons in mediating leptin action on body weight regulation. Thus, to fully appreciate the role of hypothalamic neural pathways in energy metabolism, it is imperative to examine the role of yet to be defined hypothalamic neurons. 
NPY is a well established orexigenic neuropeptide. Despite its broad expression in the brain (Leibowitz, 1991; Thorsell and Heilig, 2002), its expression in the hypothalamus is particularly abundant (Kalra and Kalra, 2004), and the hypothalamus is the predominant site that mediates its orexigenic action (Leibowitz, 1991; Pu et al., 1999). Specifically, site-specific injections of NPY to the paraventricular hypothalamic nucleus $(\mathrm{PVH})$ or lateral hypothalamus (LH) induce robust feeding (Lee and Stanley, 2005). It appears that the activity of Arc NPY/AgRP neurons correlates with feeding levels (Aponte et al., 2011; Krashes et al., 2011). Importantly, NPY neuronal activity is increased after fasting and before the dark cycle in rodents (Takahashi and Cone, 2005; Krashes et al., 2013), suggesting a role for NPY in fastinginduced hyperphagia and nocturnal feeding. In addition, the development of NPY/AgRP neurons, an orexigenic group of neurons in the brain, is not complete until early postnatal age (Xu et al., 2005), suggesting a role for NPY/AgRP neurons in postnatal feeding. Interestingly, NPY expression peaks around the postweaning age, during which its expression is highly sensitive to nutritional changes (Grove and Smith, 2003; Leibowitz et al., 2005; Rocha et al., 2014), supporting an importance of NPY in postweaning feeding. However, the neural pathways that mediate the NPY action and regulate feeding in the postweaning period remain poorly understood.

The hypothalamus contains abundant GABAergic neurons, especially the arcuate (Arc), dorsomedial (DMH), and lateral hypothalamus (Xu and Tong, 2011). Notably, AgRP/NPY neurons represent one of the best studied GABAergic groups of neurons. GABA release from AgRP/NPY neurons promotes feeding through projections to the $\mathrm{PVH}$ and a few other extrahypothalamic sites (Tong et al., 2008; Wu et al., 2009; Atasoy et al., 2012). Interestingly, GABA release from these neurons to the parabrachial nucleus is not sufficient to drive feeding, but is required to prevent anorexia (Wu et al., 2009). These observations suggest the importance for GABA release in feeding regulation. Consistent with this, delivery of GABA or its analogs to the LH and PVH induces feeding (Stanley et al., 1993b; Pu et al., 1999; Lee and Stanley, 2005). However, the role of GABA release from the vast majority of non-POMC, non-AgRP hypothalamic neurons is not clear.

Cre recombinase driven by the pancreas duodenum homeobox 1 promoter (Pdx1-Cre) expresses abundantly in the $\mathrm{DMH}$, $\mathrm{LH}$, Arc, and pre-optic area (POA) of the hypothalamus (Honig et al., 2010; Song et al., 2010; Wicksteed et al., 2010). Importantly, outside the hypothalamus, Pdx1-Cre is only expressed in serotoninergic neurons of the dorsal raphae and glutamatergic neurons of the inferior olivary nucleus (ION) of the brain (Song et al., 2010). Since Vgat is not expressed in the mouse pancreas (Kong et al., 2012), Pdx1-Cre could be used to examine specific Vgat function in the hypothalamus. Toward this, this study aimed to explore the function of hypothalamic non-POMC, non-AgRP GABAergic neurons in feeding regulation.

\section{Materials and Methods}

Animal care. Mice were housed at $22-24^{\circ} \mathrm{C}$ with a $12 \mathrm{~h}$ light/dark cycle with food and water provided ad libitum. Animal care and procedures were approved by the University of Texas Health Science Center at Houston Institutional Animal Care and Use Committee. Breeding pairs (male Pdx1-Cre:Vgaftlox/flox mice and female Vgaftlox/flox mice and male Sim1Cre: $\gamma 2^{\text {flox/flox }}$ mice and female $\gamma 2^{\text {flox/flox }}$ mice) were maintained to generate the study subjects. To visualize $P d x 1$-Cre expression, $P d x 1$-Cre mice were crossed with B6.Cg-Gt(ROSA)26Sortm9(CAG-tdTomato)Hze/J mice (Ai9 mice, purchased from The Jackson Laboratory) to generate $P d x 1$-Cre:Ai9 mice, in which Cre expression can be directly visualized by
tdTomato, a variant RFP, under fluorescent microscopes (Madisen et al., 2010).

Studies with intracerebroventricular injections. The protocol for the implantation of intracerebroventricular cannulas to the right lateral ventricle was the same as previously described (Tong et al., 2007). After 1 week recovery, mice were used for food intake studies after $2 \mathrm{~h}$ fasting in early morning with intracerebroventricular bolus injections of saline $(2 \mu \mathrm{l})$, NPY $(4 \mu \mathrm{g} / 2 \mu \mathrm{l})$, or Muscimol ( $4 \mu \mathrm{g} / 2 \mu \mathrm{l})$. Overnight fasting was used to induce fasting-induced hyperphagia.

In situ hybridization. RNAscope Multiple Fluorescent Assay, a novel ISH technique designed to visualize multiple cellular RNA targets in fresh frozen tissues (Wang et al., 2012), was used for detecting the colocalization of Vgat and Vglut2 in the brain (Advanced Cell Diagnostics).

Body weight, body length, and food Intake. Weekly body weight was monitored on all genotypes of mice fed standard mouse chow (Teklad F6 Rodent Diet 8664, $4.05 \mathrm{kcal} / \mathrm{g}, 3.3 \mathrm{kcal} / \mathrm{g}$ metabolizable energy, $12.5 \%$ kcal from fat; Harlan Teklad) from 1- to 20 -week-old mice. Weekly growth rate was expressed as net increase in body weight during the week. Body length was measured as the distance between the tip of nose and the base of tail in mice under anesthesia. Weekly food intake was measured from individually housed mice from 3- to 15 -week old mice. Normalized food intake was calculated by dividing weekly food intake by the average of body weights measured at the beginning and at the end of the week.

Immunohistochemistry assays. The immunohistochemistry studies used the previously described protocol (Xu et al., 2012). Primary antibodies against $\beta$-endorphin (1:1000; Phoenix Pharmaceuticals), orexin (1:2000; Phoenix Pharmaceuticals), melanin-concentrating hormone (MCH; 1:200; Phoenix Pharmaceuticals), pSTAT3 (1:400; Cell Signaling Technology), and tryptophan hydroxylase 2 (TPH2; 1:1000; Millipore) were used. Sections were visualized and photographed with a TCS SP5 confocal microscope (Leica). For the pSTAT3 experiment, Pdx1-Cre:Ai9 mice were administered either saline or leptin ( $2 \mathrm{mg} / \mathrm{kg}$ body weight, i.p.) and perfused 45 min later.

Brain slice electrophysiological recordings. Brain slices were prepared from 4 - to 6-week-old mice. Coronal brain slices $(350 \mu \mathrm{m})$ were cut in ice-cold ACSF containing the following (in $\mathrm{mM}$ ): $124 \mathrm{NaCl}, 5 \mathrm{KCl}, 1.25$ $\mathrm{NaH}_{2} \mathrm{PO}_{4}, 1.3 \mathrm{MgSO}_{4}, 2 \mathrm{CaCl}_{2}, 26 \mathrm{NaHCO}_{3}$, and 11 glucose and adjusted to $\mathrm{pH} 7.4$ by bubbling with $95 \% \mathrm{O}_{2} / 5 \% \mathrm{CO}_{2}$. Slices containing the $\mathrm{PVH}$ were immediately transferred to a holding chamber and submerged in oxygenated ACSF. Slices were recovered for at least $1 \mathrm{~h}$ at $32^{\circ} \mathrm{C}$ before transferring to a recording chamber. ACSF at $32^{\circ} \mathrm{C}$ was perfused into slice chambers with $\sim 2 \mathrm{ml} / \mathrm{min}$ flow rate regulated by Minipuls 3 peristaltic pump (Gilson).

To minimize potential background difference in electric properties of diverse PVH neurons, we focused on PVH neurons located in the dorsomedial part of PVH for recording. For voltage-clamp recordings, glass electrodes (4-6 M $\Omega$ ) were filled with internal solution containing the following (in $\mathrm{mM}$ ): $145 \mathrm{~K}$ gluconate, 10 HEPES, $0.2 \mathrm{EGTA}, 1 \mathrm{MgCl}_{2}, 4$ MgATP, $0.3 \mathrm{Na}_{2} \mathrm{GTP}$, and $10 \mathrm{Na}_{2}$-phosphocreatine and adjusted to $\mathrm{pH}$ 7.3 with $\mathrm{KOH}$. For voltage-clamp recordings, spontaneous IPSCs were recorded at the holding potential of $0 \mathrm{mV}$. Recording pipettes were filled with cesium-based intracellular solution containing the following (in mm): $120 \mathrm{CsCH}_{3} \mathrm{SO}_{3}, 20$ HPEPs, 0.4 EGTA, 5 TEA-Cl, $2 \mathrm{MgCl}_{2}, 2.5$ MgATP, 0.3 GTP, 1 QX-314, and $10 \mathrm{Na}_{2}$-phosphocreatine, pH 7.3.

Throughout the recording experiments, $1 \mathrm{~mm}$ kynurenic acid was used to block glutamate-mediated EPSCs. At the end of experiments, $20 \mu \mathrm{M}$ bicuculline was applied to the bath to confirm the nature of GABA-A receptor-mediated currents. All recordings were made using a Multiclamp 700B amplifier (Molecular Devices), and data were digitized at 10 $\mathrm{kHz}$ and filtered at $2 \mathrm{kHz}$ using pClamp 10.3 (Molecular Devices). Data were analyzed off-line with Clampfit and Mini Analysis software (Synaptosoft).

Comprehensive Lab Animal Monitoring System measurements. Energy expenditure was measured by oxygen consumption by indirect calorimetry. Individual housed mice were maintained on chow diet at $4-5$ weeks of age. Mice were placed at room temperature $\left(22-24^{\circ} \mathrm{C}\right)$ in chambers of a Comprehensive Lab Animal Monitoring System (CLAMS; Columbus Instruments). Food and water were provided ad libitum. Mice were ac- 

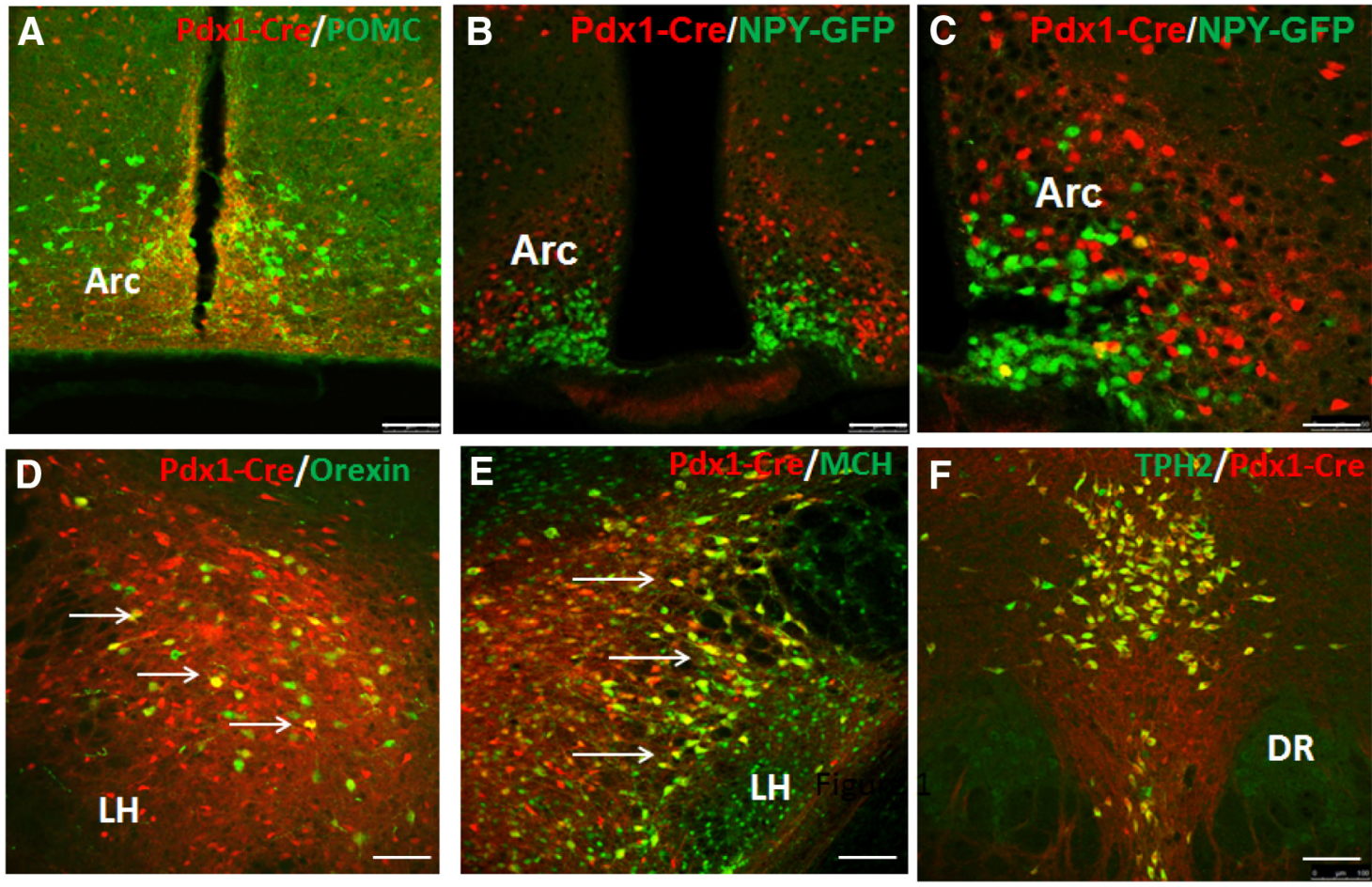

Figure 1. Pdx1-Cre neurons are non-P0MC, non-AgRP neurons in the hypothalamus. Immunostainings of the brain were performed for the indicated markers ( $g r e e n$ ) and merged pictures were presented for both green and red (dsRed-positive Pdx1-Cre neurons). $\boldsymbol{A}$, Immunostaining for $\beta$-endorphin, a cleaved product of P0MC neurons of Pdx1-Cre:Ai9 reporter mice. $B$, GFP immunostaining for NPY/AgRP neurons in Pdx1-Cre:Ai9:NPY-GFP mice. $\boldsymbol{C}$, The same in $\boldsymbol{B}$ but shown in a higher magnification. $\boldsymbol{D}, \boldsymbol{E}$, Immunostaining for orexin $(\boldsymbol{D})$ and MCH $(\boldsymbol{E})$ in the lateral hypothalamus. $\boldsymbol{F}$, Immunostaining for TPH2, a marker for serotoninergic neurons in the dorsal raphae. DR, dorsal raphei. Scale bars: $A, B, D-F, 100 \mu \mathrm{m} ; C, 50 \mu \mathrm{m}$.

climatized in the chambers for at least $48 \mathrm{~h}$ before data collection. Food intake, $\mathrm{O}_{2}$ consumption, and beam break data were collected.

Locomotion and body temperature measurements using the E-mitter system. As previously reported (Xu et al., 2014), precalibrated sensitive transmitters (PDT-4000 G2 E-Mitter sensors; Respironics) were used for performing telemetric measurements. For measuring body temperature and locomotor activity, mice were anesthetized with ketamine/xylazine and then E-Mitters were implanted in the space under the skin between the scapulae. For core body temperature monitoring, E-Mitters were placed into the peritoneal cavity. Mice were allowed 1 week recovery before all data were collected. Signals emitted by the E-Mitter transponders were sensed by a receiver positioned underneath the animal's housing cage and analyzed using VitalView software (Respironics). Locomotor activity counts are recorded as a gross motor activity indicator. For all experiments, activity counts and temperature measurements were taken every $1 \mathrm{~min}$. All mice were acclimated for at least $3 \mathrm{~d}$ and then data were collected for $24 \mathrm{~h}$. Multiple series of data at the same collected time point and from the same genotype mice were summed and then averaged to get their mean temperature and movement.

Ghrelin measurements. Tail blood was obtained at 9:00 A.M. and 7:00 P.M., which was used to measure ghrelin levels using a ghrelin ELISA kit from EMD Millipore (a gift from Dr. Yuxiang Sun of Baylor College of Medicine, Houston, TX) according to the manufacturer's instructions.

Statistical analysis. All data were presented as mean \pm SEM, and comparison between means was performed with an appropriate statistical analysis according to group numbers and treatments using Prism 6.0 with $p<0.05$ indicating statistical significance. Tukey multiplecomparison was used for two-way ANOVA.

\section{Results}

Hypothalamic Pdx1-Cre neurons are neither POMC nor AgRP neurons

To examine Pdx1-Cre expression, we crossed Pdx1-Cre mice with Ai9 reporter mice (Madisen et al., 2010), which express ds-Red in a Cre-dependent manner. Pdx1-Cre was previously reported to express abundant Cre in the Arc, DMH, LH, and POA, as well as in the dorsal raphae and ION (Honig et al., 2010; Song et al., 2010). To examine whether POMC neurons express Pdx1-Cre, we use the $\beta$-endorphin antibody to label POMC neurons in Pdx1-Cre:Ai9 reporter mouse brain sections. POMC neurons were not found to express Pdx1-Cre in the Arc (Fig. 1A). Given the colocalization between AgRP and NPY in AgRP neurons of Arc (Hahn et al., 1998), we crossed NPY-GFP mice with $P d x 1$-Cre:Ai9 reporter mice to assess whether AgRP neurons express Pdx1-Cre. The vast majority of AgRP neurons were not Pdx1-Cre neurons (Fig. 1B), which can be better appreciated in an amplified picture (Fig. 1C). Thus, Pdx1-Cre targets a major subset of non-POMC, non-AgRP neurons in the hypothalamus. $\mathrm{MCH}$ and orexin are two well studied neuropeptides in the $\mathrm{LH}$, in which Pdx1-Cre also showed abundant expression. Pdx1-Cre neurons in the LH partially overlapped with orexin neurons (Fig. $1 D$ ) and $\mathrm{MCH}$ neurons (Fig. $1 E$ ) in the LH. Of note, almost all Pdx1-Cre neurons in the dorsal raphae express TPH2 (Fig. $1 F$ ), a marker for serotoninergic neurons, suggesting the vast majority of Pdx1-Cre neurons in this region are serotoninergic in nature.

\section{Pdx1-Cre neurons partially overlap with LepR neurons}

LepR neurons represent a key subset of hypothalamic neurons for body weight regulation. To examine whether Pdx1-Cre neurons significantly overlap with LepR neurons, we colocalized Pdx1Cre with leptin-induced p-STAT3 expression (Münzberg et al., 2007). Compared with saline treatment, leptin induced a large number of p-STAT3-expressing neurons in the DMH and Arc (Fig. $2 A, B$, compare $A-1$ to $B-1$ and $A-2$ to $B-2$ ), in addition to a few other sites. Interestingly, a subset of Pdx1-Cre neurons in the $\mathrm{DMH}$ (Fig. 2B-1) and the vast majority of Pdx1-Cre neurons in the Arc were negative for p-STAT3 (Fig. 2B-2). These results 
Pdx1-Cre/pSTAT3
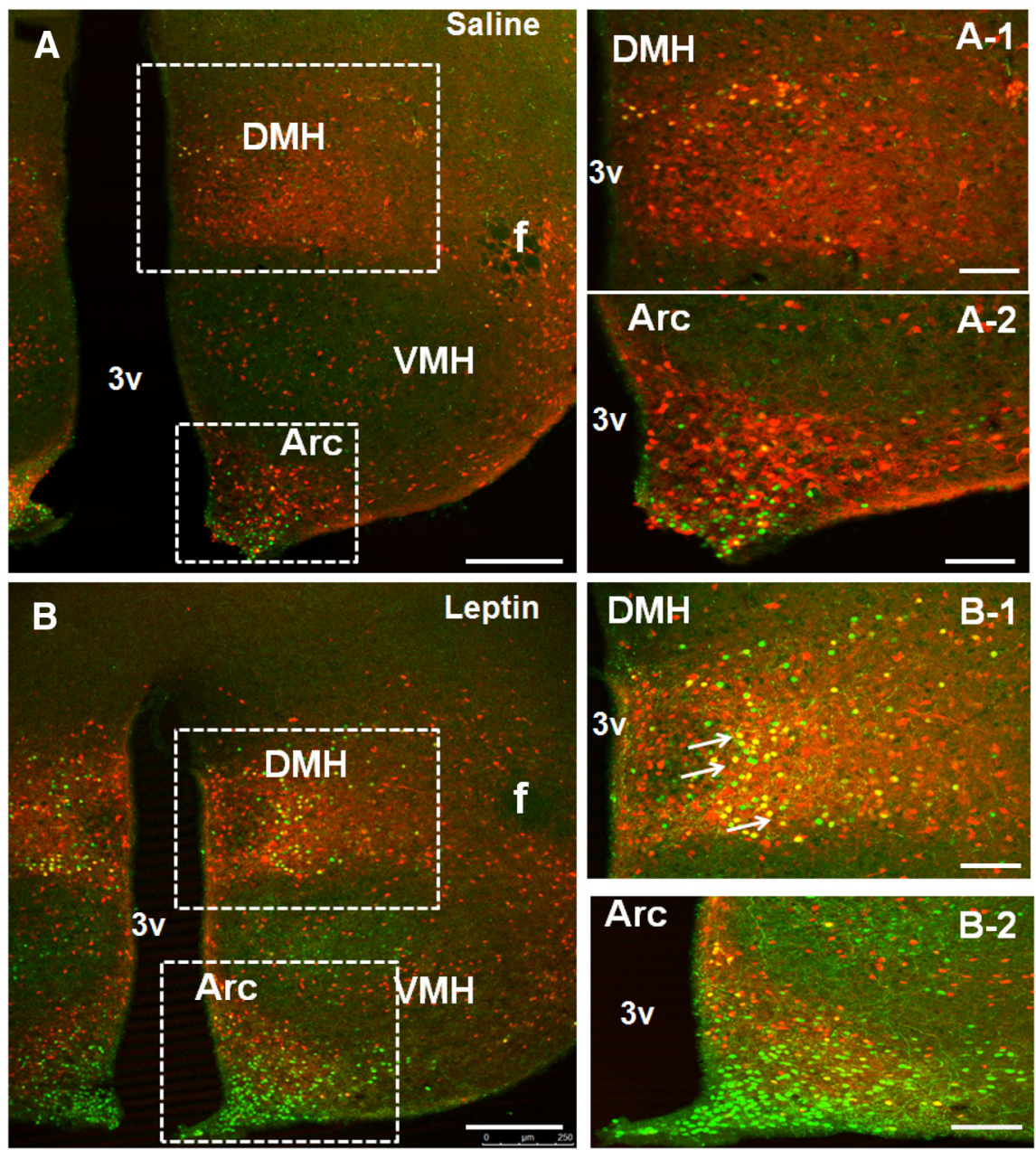

Figure 2. Pdx1-Cre neurons partially overlap with LepR neurons. Pdx1-Cre:Ai9 mice were intraperitoneally administered saline $(\boldsymbol{A})$ or leptin $(\boldsymbol{B})$ and brain sections were immunostained for $\mathrm{p}$-STAT3 in green. The boxed areas in $\boldsymbol{A}$ were enlarged in $\boldsymbol{A}-\mathbf{1}$ for DMH and in $\boldsymbol{A}-\mathbf{2}$ for Arc, and those in $\boldsymbol{B}$ were enlarged in $\boldsymbol{B}-\mathbf{1}$ for DMH and in $\boldsymbol{B}-\mathbf{2}$ for Arc. Arrows point to neurons with coexpression of Pdx1-Cre and p-STAT3. VHM, ventromedial hypothalamus; DMH, dorsomedial hypothalamus; Arc, arcuate nucleus; $\mathrm{f}$, fornix; $3 \mathrm{~V}$, the third ventricle. Scale bars: $A, B, 250 \mu \mathrm{m} ; \boldsymbol{A}-\mathbf{1}, \boldsymbol{A}-\mathbf{2}, \boldsymbol{B}-\mathbf{1}, \boldsymbol{B}-\mathbf{2}, 100 \mu \mathrm{m}$.

suggest that Pdx1-Cre neurons only partially overlap with LepR neurons in the hypothalamus.

\section{Deletion of Vgat by Pdx1-Cre in the hypothalamus}

To examine the role of GABA release from Pdx1-Cre neurons, we bred Pdx1-Cre mice with mice bearing floxed Vgat gene (Vgat flox/ flox mice). Specific deletion of Vgat was examined by the RNA scope technology, which can visualize a single RNA molecule in cells (Xu et al., 2013). We also included ISH for Vglut2 (also named Slc17a6), a marker for glutamatergic neurons, to serve as a control. Our previous results showed that Pdx1-Cre targets $\sim 80 \%$ of GABAergic neurons in the LH (Wu et al., 2015). In addition to the LH of control mice, Vgat was also found to be abundantly expressed in the Arc (Fig. 3A), DMH (Fig. 3B), and POA (Fig. $3 C$ ), in which Pdx1-Cre expression is abundant. In contrast, Vgat was not present in ION (Fig. 3D). In Pdx1-Cre: Vgat flox/flox mice, Vgat was substantially deleted in the Arc (Fig. $3 E$ ), DMH (Fig. 3F), and POA (Fig. 3G), and only Vglut2 and no Vgat was present in the ION (Fig. $3 H$ ). Combined with our previous data on LH neurons (Wu et al., 2015), these data suggest that
Pdx1-Cre targets a major subset of nonPOMC, non-AgRP GABAergic neurons in the hypothalamus.

\section{Deletion of Vgat in Pdx1-Cre neurons} impairs GABA release to $\mathrm{PVH}$ neurons In $P d x 1-C r e: A i 9$ reporter mice we found abundant ds-Red-positive fibers in the $\mathrm{PVH}$, but not in the surrounding brain regions (Fig. 3I), suggesting that Pdx1Cre neurons send projections to the $\mathrm{PVH}$. If a significant portion of $\mathrm{PVH}$-projecting fibers are GABAergic, then it is possible that Vgat deletion in Pdx1-Cre neurons may cause reduced GABA release to $\mathrm{PVH}$ neurons. To examine this possibility, we recorded spontaneous GABA-mediated IPSCs (sIPSCs) in PVH neurons on brain slices of control and Pdx1-Cre:Vgat flox/flox mice (Fig. 3J). Whole-cell recordings from brain slices showed that the frequency, but not the amplitude, of sIPSCs of PVH neurons in Pdx1-Cre: Vgat flox/flox mice was reduced by two-thirds, com-

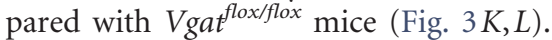
These results suggest that Vgat deletion in Pdx1-Cre neurons impairs GABA release and that the majority of GABAergic input to the $\mathrm{PVH}$ originates from GABAergic Pdx1-Cre neurons within the hypothalamus.

\section{GABA release from hypothalamic neurons is required for postweaning feeding and NPY hyperphagia}

To determine the physiological role of GABA release from Pdx1-Cre neurons, we monitored body weight of $P d x 1-C r e$ : Vgat ${ }^{\text {flox/flox }}$ mice. These mice exhibited reduced body weight from the age of 3 weeks onward in both males (Fig. 4A) and females (data not shown). Of note,

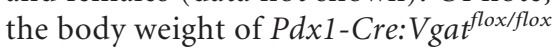
mice at the ages of 2, 3, and 5 weeks were reported previously (Song et al., 2010). A closer look at their body weight curve revealed that from the age of 5 weeks onward, body weight curves of Pdx1-Cre:Vgat flox/flox mice and their controls remained parallel to each other. Interestingly, when growth rate (net body weight growth/each week) was calculated, control mice showed a period of rapid growth rate during the ages of weeks $4-5$, a period right after weaning, whereas $P d x 1-C r e$ : $V$ gaf $f^{\text {flox/flox }}$ mice exhibited a dramatic reduction in growth rate in both males (Fig. $4 B$ ) and females (data not shown). Notably, growth rates were not different between genotypes at 2 weeks of age and after 6 weeks of age, suggesting that the reduction in growth rate is specific for the postweaning period. To effectively compare food intake between mice of different ages with dramatic body weight difference, we normalized their weekly food intake by their body weight. While control mice exhibited a high level of normalized food intake at the age of 4-5 weeks, which coincided with their rapid growth rate, $P d x 1$ Cre:Vgat flox/flox mice showed significantly blunted feeding (Fig. 4C), suggesting a role for GABAergic Pdx1-Cre neurons 

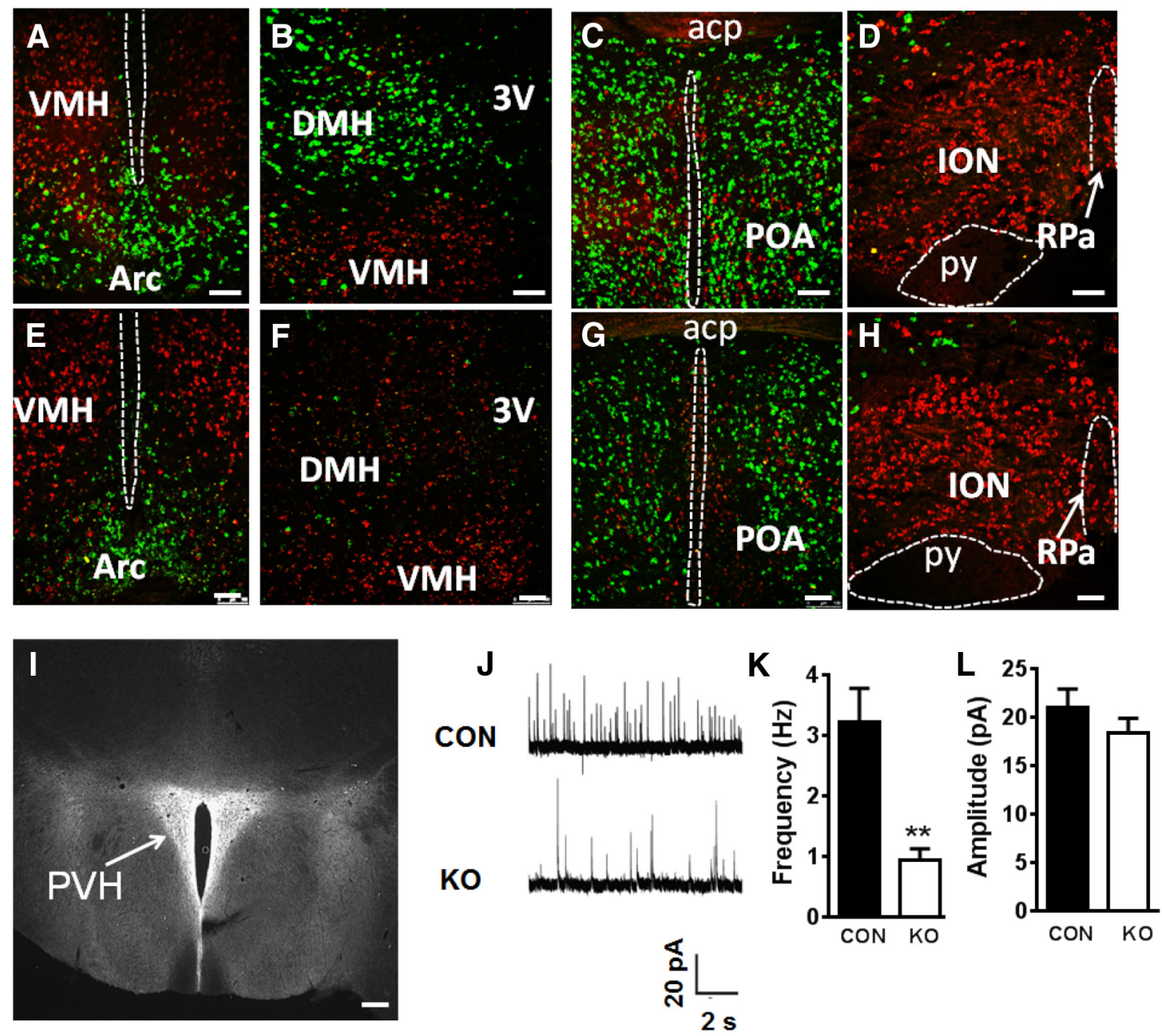

Figure 3. Deletion of Vgat in Pdx1-Cre neurons impaired GABA release to PVH. $\boldsymbol{A}-\boldsymbol{H}$, Vgat (green) and Vglut2 (red) mRNA expression by ISH in the $\operatorname{Arc}(\boldsymbol{A}, \boldsymbol{E}), \mathrm{DMH}(\boldsymbol{B}, \boldsymbol{F}), \mathrm{POA}(\boldsymbol{C}, \boldsymbol{G})$, and ION $(\boldsymbol{D}$, $\boldsymbol{H})$. Sections are from Vgat floxflox $(\boldsymbol{A}-\boldsymbol{D})$ and from Pdx1-Cre:Vgat floxfflox mice $(\boldsymbol{E}-\boldsymbol{H})$. In Pdx 1-Cre:Vgat floxfflox mice, Vglut2 expression is not changed and Vgat is largely deleted in the DMH and reduced in the Arc and POA. I, Fibers from Pdx1-Cre neurons shown by ds-Red fluorescence in the PVH of Pdx1-Cre:Aig reporter mice. J, Representative traces showing sIPSCs in a PVH neuron recorded from $V g a t^{f l x}{ }^{\prime f l o x}$ mouse (CON, top) and a Pdx 1-Cre:Vgat flox/flox mice (KO, bottom). $\boldsymbol{K}, \boldsymbol{L}$, Quantification of the frequency $(\boldsymbol{K})$ and amplitude $(\boldsymbol{L})$ of sIPSCs recorded from PVH neurons in two groups of mice; $n=19,{ }^{* *} p<0.01$, unpaired Student's $t$ tests. Acp, anterior commissure (posterior part); py, pyramid tracts; RPa, raphe pallidus; PVH, paraventricular hypothalamus; CON, Vgaf floxfflox mice; KO, Pdx1-Cre:Vgat ${ }^{\text {floxflox }}$ mice; POA, preoptic area; ION, inferior olive nucleus; $3 \mathrm{~V}$, the third ventricle. Scale bars: $\boldsymbol{A}-\boldsymbol{H}, 50 \mu \mathrm{m} ; \boldsymbol{I}, 100 \mu \mathrm{m}$. Data presented as means \pm SEM.

in postweaning feeding. Consistent with the defect in the postweaning period, a key developmental stage, Pdx1-Cre:

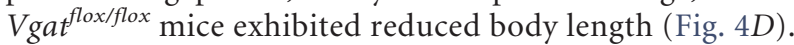

Since previous results suggest a potential role for NPY in postweaning feeding (Leibowitz et al., 2005), we examined whether Pdx1-Cre:Vgat flox/flox mice show defects in NPY-induced

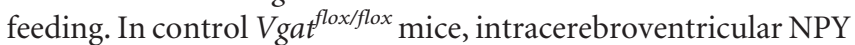
induced robust feeding during the first $4 \mathrm{~h}$, compared with saline (Fig. 5A). However, in Pdx1-Cre:Vgat flox/flox mice, the same dose of NPY failed to induce feeding (Fig. 5A). As increased NPY action contributes to refeeding after fasting, we also measured fasting-induced refeeding in these mice. While control mice exhibited robust feeding after fasting (Fig. 5B), Pdx1-Cre: $V g a t^{\text {flox/flox }}$ mice showed a greatly attenuated feeding response to fasting (Fig. 5B). We also tested the effect of Muscimol, a GABA-A receptor agonist known to induce feeding ( $\mathrm{Pu}$ et al., 1999). Muscimol produced similar hyperphagic responses between control and $P d x 1$-Cre: Vgat flox/flox mice (Fig. 5C), suggesting that Pdx1-Cre:Vgat flox/flox mice have no defects in executing

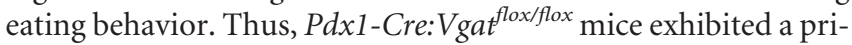
mary defect in hyperphagic response to NPY, suggesting an im- portant role for GABA release from Pdx1-Cre neurons in mediating NPY action on feeding regulation.

\section{GABA release from hypothalamic neurons is required for} nocturnal feeding

Since NPY may promote nocturnal feeding (Sindelar et al., 2005; Krashes et al., 2013), we also monitored hourly food intake for $2 \mathrm{~d}$ in 4-week-old Pdx1-Cre:Vgat flox/flox mice. Control Vgat flox/flox mice showed typical nocturnal feeding, which was significantly blunted in Pdx1-Cre:Vgat flox/flox mice (Fig. 6A). This is consistent with the notion that GABA release from Pdx1-Cre neurons mediates NPY action on feeding. Of note, blunted nocturnal feeding was persistent when measured in 8-week-old Pdx1-Cre: $V g a t^{f l o x / f l o x}$ mice (data not shown). Interestingly, we noticed that, while ghrelin levels were not different between groups when measured in early morning, they were significantly higher in $P d x 1$ Cre: Vgat flox/flox mice in late afternoon, compared with controls (Fig. 6B), which was presumably from a compensatory secretion of ghrelin in response to diminished feeding during the dark period. Nocturnal feeding is normally associated with increased energy expenditure, locomotion, and body temperature. We thus 
A
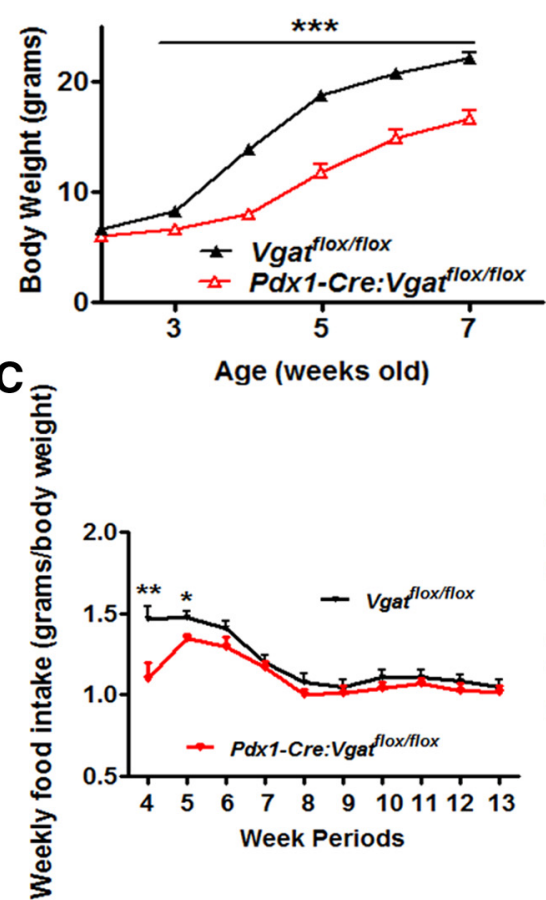

Figure 4. Reduction in postweaning feeding and growth in $P d x 1$-Cre:Vgat floxfflox mice. $A$, Body weight curve of males from the age of 2 weeks onward. $\boldsymbol{B}$, Growth rate expressed as net body weight gain per week in males. $\boldsymbol{C}$, Weekly food intake expressed as net food consumption per body weight in grams. $D$, Body length measured in 8 - to 10-week old males. Data presented as mean \pm SEM, $n=6-8 ;{ }^{*} p<0.05$ and ${ }^{* * *} p<0.001$ analyzed by Student's $t$ tests.

also monitored these parameters in Pdx1-Cre: Vgat flox/flox mice and found that, consistent with their reduced nocturnal feeding, these mice showed reduced energy expenditure (Fig. 6C), locomotion (Fig. 6D,E), and body temperature (Fig. 6F). These results suggest that GABA release from a major subset of nonPOMC, non-AgRP neurons is required for nocturnal hyperphagia and its associated hyperactivity, increased energy expenditure, and body temperature.

\section{Disrupted GABAergic input to the PVH reduced postweaning} growth and attenuated NPY hyperphagia

We previously reported that mice lacking the $\gamma 2$-subunit in the PVH (Sim1-Cre: $\gamma 2^{\text {flox/flox }}$ mice) exhibited reduced feeding at 4-5 weeks of age (Wu et al., 2015). The reduced nocturnal feeding supports that the PVH is one of the downstream targets that contribute significantly to the action of GABA released from Pdx1-Cre neurons. We next determined whether disrupting GABAergic input to Sim 1 neurons impairs the growth rate of Sim1-Cre: $\gamma 2^{\text {flox/flox }}$ mice. A reduction in growth rate was observed in Sim1-Cre: $\gamma 2^{\text {flox/flox }}$ mice $\sim 4$ weeks of age, compared with controls (Fig. 7A), which was also observed in females (data not shown). While control $\gamma 2^{\text {flox/flox }}$ mice showed high levels of rapid growth rate (Fig. $7 B$ ) during the postweaning period, Sim1-Cre: $\gamma 2^{\text {flox/flox }}$ mice showed a significantly reduced growth rate (Fig. $7 B$ ). Sim1-Cre: $\gamma 2^{\text {flox/flox }}$ mice exhibited a significant reduction in feeding during week 4 and showed a trend of reduced feeding level in weeks 5 and 6 (Fig. 7C), which remained throughout their adult life (data not shown). Consistent with a reduced feeding during the weaning period, a key period for growth, Sim1-Cre: $\gamma 2^{\text {flox/flox }}$ mice exhibited reduced body length (Fig. 7D).

To further examine whether GABAergic input to the $\mathrm{PVH}$ mediates the NPY effect on feeding, we also measured food intake in response to NPY. While control mice exhibited a normal hyperphagic response to NPY, Sim1-Cre: $\gamma 2^{\text {flox/flox }}$ mice showed significantly blunted food intake response to NPY (Fig. 7E), although the degree in difference was smaller than those observed in Pdx1-Cre:Vgat flox/flox mice. We previously reported that Sim1-Cre: $\gamma 2^{\text {flox }}$ flox mice exhibited reduced nocturnal feeding (Wu et al., 2015). Associated with this, these mice showed specific attenuation in $\mathrm{O}_{2}$ consumption during the dark period (Fig. $7 F$ ), suggesting an attenuated feedinginduced energy expenditure. These results demonstrate that PVH neurons are one of the important downstream targets of GABAergic input from Pdxl-Cre neurons in mediating postweaning feeding and NPY hyperphagia.

\section{Discussion}

Prevailing studies on hypothalamic GABAergic action in feeding control primarily focus on AgRP neurons (Wu et al., 2009; Krashes et al., 2011; Atasoy et al., 2012). Here we showed that, within the hypothalamus, Pdx1-Cre neurons were distinct from POMC and AgRP neurons. Of note, Vgat is not expressed in pancreatic islets (Kong et al., 2012), and Pdx1Cre neurons in the dorsal raphei and ION were shown to be serotoninergic and glutamatergic, respectively. Our data showed that disruption of GABA release from hypothalamic non-AgRP, non-POMC neurons impaired postweaning feeding and growth rate. Moreover, these neurons provide direct GABAergic projections to $\mathrm{PVH}$ neurons, and disruption of GABAergic input to $\mathrm{PVH}$ neurons resulted in similar defects, although to a lesser degree. In both animal models, the growth rate was not altered during the first two postnatal weeks, and the body weight remained parallel to that of controls from the age of 6 weeks onward, suggesting a specific defect in postweaning feeding. The specific defect may indicate that GABAergic input from Pdx1-Cre neurons to $\mathrm{PVH}$ neurons is most prominent during the weaning period to ensure sufficient feeding that is required for rapid developmental growth. Of note, during the postweaning period, the switch from liquid milk to solid chow food coincides with an increased demand of a high level of feeding during this period of rapid growth (Eisen and Leatherwood, 1978). Thus, this study revealed a key role for hypothalamic non-POMC, non-AgRP neurons GABAergic neurons in postweaning feeding, and will have significant impact on the understanding of early life nutrition and its role in adult metabolism (Lee and Blackshaw, 2014).

Deletion of LepR in GABAergic neurons and disruption of GABA release from LepR neurons both cause obesity (Vong et al., 2011; Xu et al., 2012). However, disruption of GABA release from Pdx1-Cre neurons led to reduced nocturnal feeding and a defective response to NPY-induced hyperphagia associated with blunted growth. These contrasting effects can be explained by the fact that a major subset of Pdx1-Cre neurons in the hypothalamus do not overlap with LepR neurons. It is likely that the hypothalamic GABAergic neurons that are labeled by Pdx1-Cre, but not LepR, neurons are required for nocturnal feeding and medi- 
A

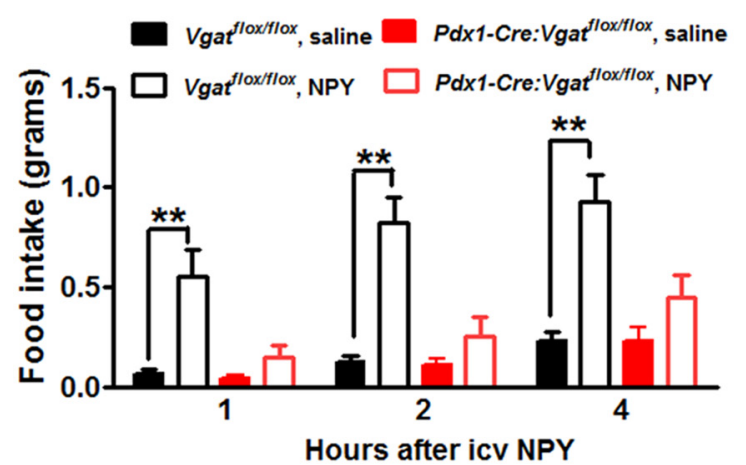

B

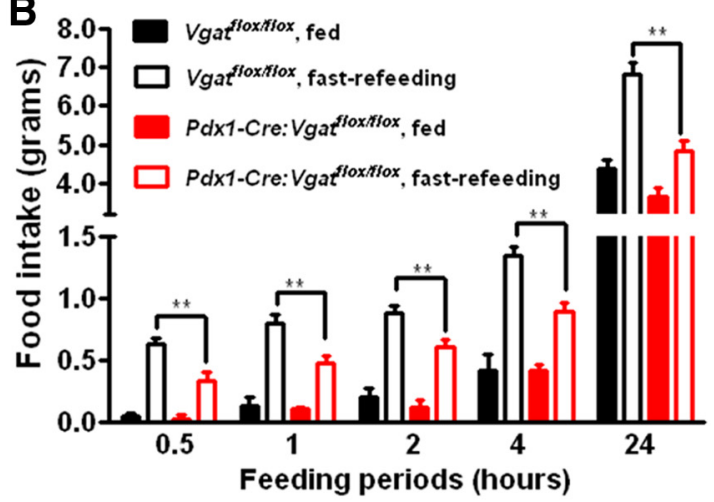

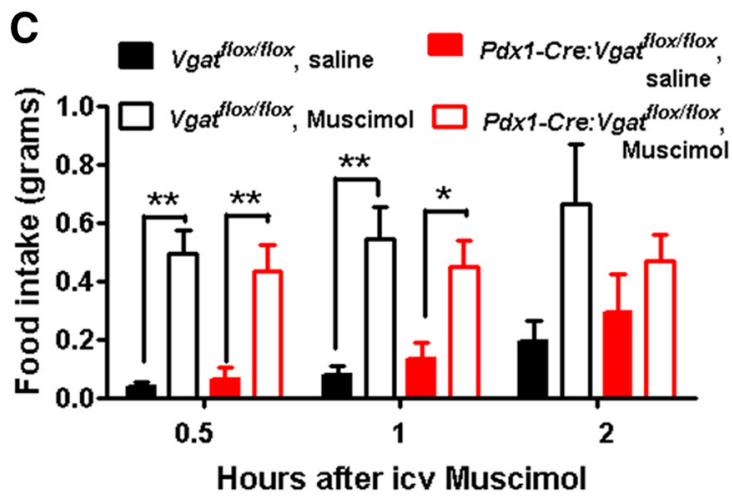

Figure 5. Blunted feeding response to NPY in Pdx1-Cre:Vgat flox/flox mice. All mice were implanted with intracerebroventricular (icv) cannulation, which was verified by angiotensin-induced drinking behavior. Food intake response male Vgat ${ }^{\text {flox/flox }}$ and Pdx1-Cre:Vgat flox/flox mice to intracerebroventricular administration of NPY (A), overnight fasting (B), and Muscimol ( $)$. All data presented as mean $\pm \mathrm{SEM}, n=5-8{ }^{*} p<0.05$ and ${ }^{* *} p<0.01$, two-way ANOVA tests followed by a Tukey correction.

ate NPY-induced feeding behavior. Thus, our results highlight an important role for a previously uncharacterized group of hypothalamic GABAergic neurons (non-POMC, non-AgRP, and non-LepR) in feeding regulation.

Our findings identified the source of GABA release that is required in feeding regulation. GABA produces robust feeding in the brain (Stanley and Leibowitz, 1984; Stanley et al., 1985; Kalra et al., 1999; Pu et al., 1999; Leinninger et al., 2009; Wu et al., 2009). However, the source of GABA release required for feeding regulation remains elusive. Recent studies on AgRP neurons showed that GABA release from these neurons is sufficient $(\mathrm{Wu}$ et al., 2009; Atasoy et al., 2012; Krashes et al., 2013), but is not required (Tong et al., 2008; Krashes et al., 2013), to drive feeding. Disruption of GABA release from hypothalamic non-POMC, non-AgRP neurons led to a reduction in postweaning and nocturnal feeding, suggesting that GABA release from these hypothalamic neurons is required to drive feeding. Among different hypothalamic regions with Pdx1-Cre expression, LH GABAergic neurons likely contribute significantly to feeding since specific disruption GABA release from LH neurons causes a reduction in feeding and is required for feeding driven by LH GABAergic neurons (Jennings et al., 2015; Wu et al., 2015). Our previous results on mice with almost complete Vgat deletion in the Arc show no obvious changes in feeding (Kong et al., 2012), arguing against a significant contribution of Arc non-POMC, non-AgRP neurons to the defect in postweaning feeding observed here. A recent study shows that DMH neurons exhibit an increasing putative inhibitory GABA input to AgRP neurons during periweaning period, arguing against a role for Pdx1-Cre GABAergic neurons in the $\mathrm{DMH}$ in the postweaning feeding phenotype observed in this study (Baquero et al., 2015). Further studies are required to specifically address the role of GABAergic neurons in the DMH, as well as in the POA, where Pdx1-Cre also shows abundant expression.

Our results have revealed an importance of hypothalamic non-POMC, non-AgRP neurons in mediating NPY hyperphagia. Disruption of GABA release from these neurons greatly attenuated NPY-induced food intake and the hyperphagia induced by fasting, a condition with increased NPY action (Takahashi and Cone, 2005). NPY/AgRP neuronal activity increases in the nocturnal period (Krashes et al., 2013), which is thought to promote nocturnal feeding (Sindelar et al., 2005). Knockdown of NPY in the DMH causes a specific reduction in nocturnal feeding in rats (Yang et al., 2009). In line with this, we found that disruption of GABA release from Pdx1-Cre neurons selectively reduced nocturnal feeding, strongly supporting a role for GABA in mediating NPY action and a role for an increased GABA release from these neurons in driving nocturnal feeding. Supporting our observations, NPY action on feeding depends on GABA-A receptors (Jonaidi and Noori, 2012). Furthermore, the LH and Arc express abundant NPY receptors (Lin et al., 2004), and multiple brain sites including the DMH, LH, and Arc have been shown to contribute to NPY-mediated feeding regulation (Stanley and Leibowitz, 1984; Stanley et al., 1993a; b; Tiesjema et al., 2007; Dailey and Bartness, 2009; Yang et al., 2009). One additional key observation supporting that hypothalamic non-POMC, non-AgRP neurons in mediating NPY hyperphagia is the reduction in postweaning feeding. NPY has been suggested to be involved in postweaning feeding. NPY expression peaks and is highly sensitive to undernutrition around weaning time (Grove et al., 2001; Grove and Smith, 2003; Rocha et al., 2014). The action of NPY on GABA release is the strongest in early postnatal life (Melnick et 

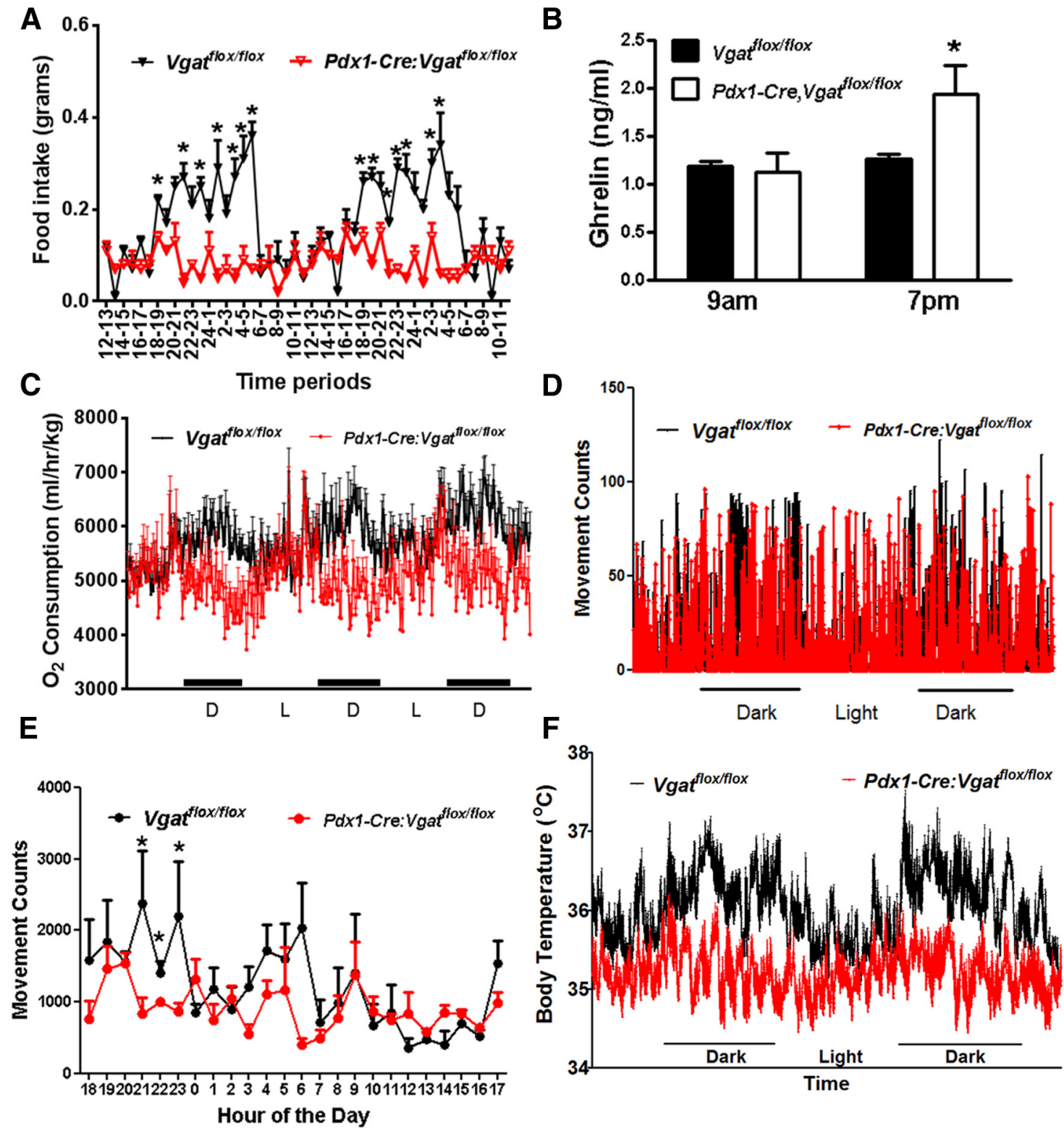

Figure 6. Altered diurnal feeding rhythms in Pdx1-Cre:Vgat floxfflox mice. A, Hourly food intake for 2 d measured in 4-week-old Vgat floxfflox and Pdx1-Cre:Vgat flox/flox mice. B, Ghrelin levels measured in blood obtained at 9:00 A.M. and 7:00 P.M. of indicated genotypes at the age of 7-8 weeks. C, Energy expenditure measured by CLAMS for $2 \mathrm{~d}$ in 4-week-old mice. D, Movement counts from a representative 8-week-old Vgat floxfflox and Pdx1-Cre:Vgat floxfflox mouse measured from beam breaks of CLAMS. D and L, dark and light periods respectively. E, Averaged movement counts measured at the age of $7-8$ weeks of age by an E-mitter system. $\boldsymbol{F}$, Real-time body temperature measurement (every minute) at the age of $7-8$ weeks of age using an E-mitter system. All data presented as mean \pm SEM; $n=5-8$ in $\boldsymbol{A}$ and $\boldsymbol{B}, n=6$ in $\boldsymbol{C}$, and $n=5-7$ in $\boldsymbol{E}$ and $\boldsymbol{F} ;{ }^{*} p<0.05$, Student's $t$ tests.

al., 2007), suggesting a role of NPY in controlling GABA neurotransmission during early key developmental periods. Collectively, our study identifies GABA as a key mediator for the NPY hyperphagic action.

Somatostatin (SST) and growth hormone (GH)-releasing hormone located in the Arc and POA are known to regulate GH secretion. As Pdx1-Cre also expresses abundantly in both regions, it is important to know whether the reduced growth in Pdx1-Cre: $V g a t^{\text {flox/flox }}$ mice is from a defective GH action. Indeed, we found that SST neurons significantly overlapped with Pdx1-Cre neurons in the POA, but not in the Arc (data not shown). However, despite the overlap, it is unlikely that defective postweaning growth in Pdx1-Cre:Vgat ${ }^{\text {flox/flox }}$ mice is a direct result of a compromised SST neuron function. First, SST-deficient mice do not exhibit reduced growth; instead they show a slightly increased body weight (Low et al., 2001). Second, the reduced growth in Pdx1-Cre:Vgat flox/flox mice is unlikely because of defective GH action since these mice exhibited a normal level of $\mathrm{GH}$ at 3 weeks of age and a tread of increased GH levels at 5 weeks of age (data not shown). Third, Pdx1-Cre: Vgat flox/flox mice exhibited, in addition to a tread of increased GH levels, reduced T3 and T4 levels in blood and reduced Igf1 expression in liver (data not shown), which are all typical signs of starvation (Boelen et al., 2008; Misra and Klibanski, 2014), suggesting that reduced feeding is the primary defect and that reduced growth is a result of reduced feeding, especially during the weaning period when rapid growth is conceivably most sensitive to nutrient insufficiency. Fourth, specific reduction in nocturnal and NPY-induced feeding suggests an inherent defect in feeding. 
A
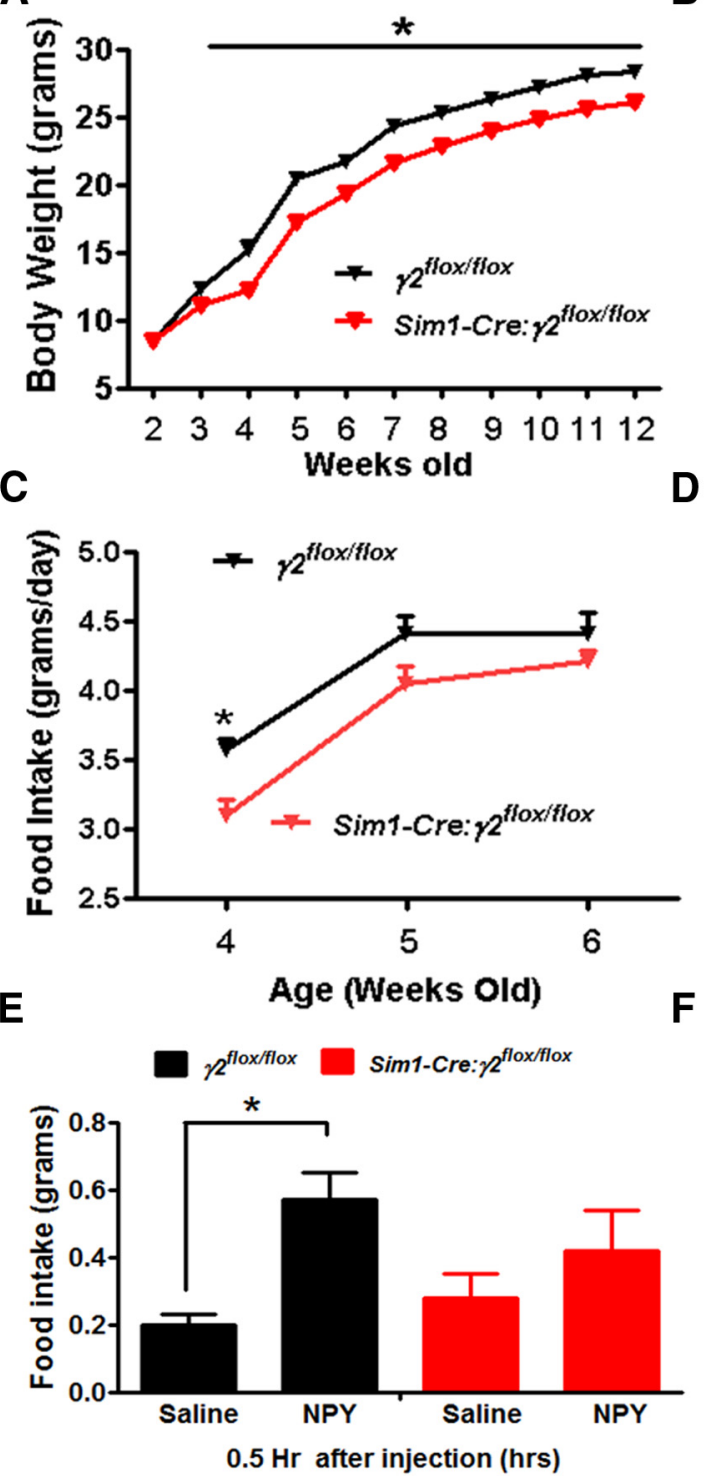

B

$\mathbf{F}$
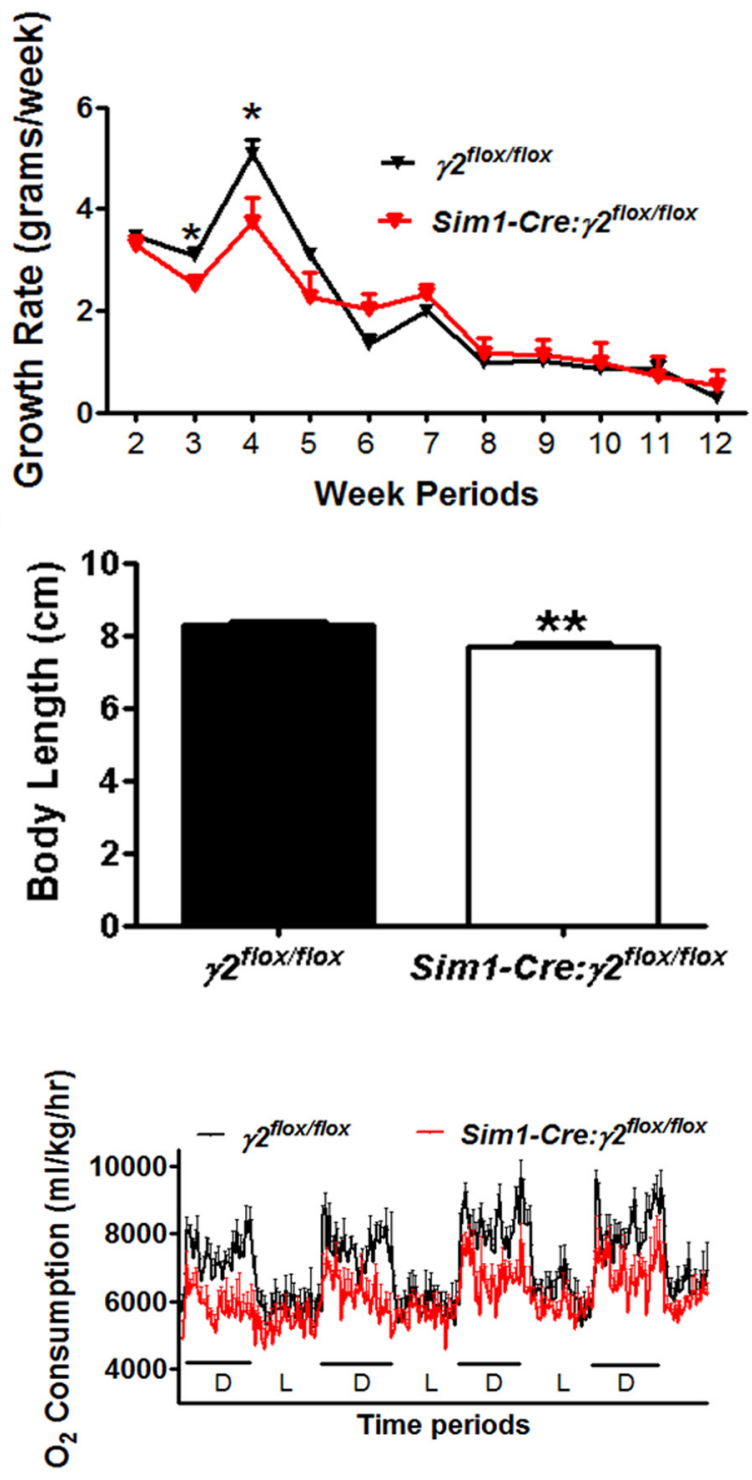

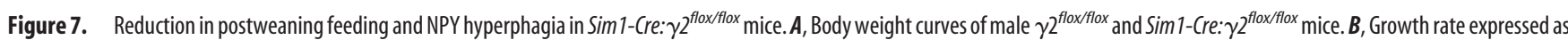
net body weight gain each week in males. C, Average daily food intake for each week during the age of weeks $4-6$ in males. D, Body length measured at the age of 5 weeks. $E$, Food intake in $\gamma 2^{f l o x}$ fllox mice and Sim 1-Cre: $\gamma 2^{\text {floxfflox }}$ mice in response to saline or NPY. $\boldsymbol{F}$, Energy expenditure measured by $\mathrm{O}_{2}$ consumption at the age of 4 weeks using CLAMS for 4 consecutive days. All data presented as mean \pm SEM; $n=8-10$ in $\boldsymbol{A}-\boldsymbol{C}, n=5-7$ in $\boldsymbol{D}$ and $\boldsymbol{E}$ and $n=6$ in $\boldsymbol{F}^{*}{ }^{*} p<0.05 ;{ }^{* *} p<0.01$, Student's $t$ tests.

GABAergic input to the PVH is involved in the integration of an array of physiologic processes, including modulating the melanocortin input from the Arc (Cowley et al., 2001), energy expenditure and feeding from the Arc (Atasoy et al., 2012; Kong et al., 2012), stress response from the prefrontal cortex (Radley et al., 2009), and circadian metabolic changes from the suprachiasmatic nucleus (Kalsbeek et al., 2008). Despite multiple origins of GABAergic input to PVH, the frequency of sIPSCs of PVH was reduced to one-third by disrupting GABA release from Pdx1-Cre neurons, suggesting a major contribution of these neurons to total GABAergic input to PVH neurons. This notion is consistent with the intense projection of Pdx1-Cre neurons to the PVH and previous observations showing strong GABAergic input to the PVH from both DMH and LH (Boudaba et al., 1996). Importantly, disruption of GABAergic input to PVH neurons led to an array of phenotypes similar to those observed in mice with disruption of GABA release from Pdx1-Cre neurons, including spe- cific reduction in postweaning feeding and growth, blunted response to NPY-induced hyperphagia, and diminished nocturnal feeding. The striking similarity suggests PVH neurons are one major downstream target of GABA released from Pdx1-Cre neurons in feeding regulation. The reduced food intake by disrupting GABA-A receptors is supported by previous observations that specific GABA injections to the PVH induce feeding ( $\mathrm{Pu}$ et al., 1999) and that reduced GABA-A receptor levels inhibit feeding (Sheng et al., 2006). A specific reduction in nocturnal feeding highlights an important role for circadian changes in GABA release to the PVH in feeding behavior.

In summary, our study identified GABA released from hypothalamic non-POMC, non-AGRP neurons as a critical downstream mediator for postweaning feeding and NPY hyperphagia, and PVH neurons as one major downstream target for the GABA action. Our results suggest that diurnal changes in hypothalamic GABA action may underline diurnal feeding behaviors. 


\section{References}

Aponte Y, Atasoy D, Sternson SM (2011) AGRP neurons are sufficient to orchestrate feeding behavior rapidly and without training. Nat Neurosci 14:351-355. CrossRef Medline

Atasoy D, Betley JN, Su HH, Sternson SM (2012) Deconstruction of a neural circuit for hunger. Nature 488:172-177. CrossRef Medline

Balthasar N, Coppari R, McMinn J, Liu SM, Lee CE, Tang V, Kenny CD, McGovern RA, Chua SC Jr, Elmquist JK, Lowell BB (2004) Leptin receptor signaling in POMC neurons is required for normal body weight homeostasis. Neuron 42:983-991. CrossRef Medline

Baquero AF, Kirigiti MA, Baquero KC, Lee SJ, Smith MS, Grove KL (2015) Developmental changes in synaptic distribution in arcuate nucleus neurons. J Neurosci 35:8558-8569. CrossRef Medline

Boelen A, Wiersinga WM, Fliers E (2008) Fasting-induced changes in the hypothalamus-pituitary-thyroid axis. Thyroid 18:123-129. CrossRef Medline

Boudaba C, Szabó K, Tasker JG (1996) Physiological mapping of local inhibitory inputs to the hypothalamic paraventricular nucleus. J Neurosci 16:7151-7160. Medline

Cowley MA, Smart JL, Rubinstein M, Cerdán MG, Diano S, Horvath TL, Cone RD, Low MJ (2001) Leptin activates anorexigenic POMC neurons through a neural network in the arcuate nucleus. Nature 411:480-484. CrossRef Medline

Dailey MJ, Bartness TJ (2009) Appetitive and consummatory ingestive behaviors stimulated by PVH and perifornical area NPY injections. Am J Physiol Regul Integr Comp Physiol 296:R877-R892. CrossRef Medline

Eisen EJ, Leatherwood JM (1978) Effect of postweaning feed restriction on adipose cellularity and body composition in polygenic obese mice. J Nutr 108:1663-1672. Medline

Grove KL, Smith MS (2003) Ontogeny of the hypothalamic neuropeptide Y system. Physiol Behav 79:47-63. CrossRef Medline

Grove KL, Brogan RS, Smith MS (2001) Novel expression of neuropeptide Y (NPY) mRNA in hypothalamic regions during development: regionspecific effects of maternal deprivation on NPY and Agouti-related protein mRNA. Endocrinology 142:4771-4776. CrossRef Medline

Hahn TM, Breininger JF, Baskin DG, Schwartz MW (1998) Coexpression of Agrp and NPY in fasting-activated hypothalamic neurons. Nat Neurosci 1:271-272. CrossRef Medline

Honig G, Liou A, Berger M, German MS, Tecott LH (2010) Precise pattern of recombination in serotonergic and hypothalamic neurons in a Pdx1cre transgenic mouse line. J Biomed Sci 17:82. CrossRef Medline

Jennings JH, Ung RL, Resendez SL, Stamatakis AM, Taylor JG, Huang J, Veleta K, Kantak PA, Aita M, Shilling-Scrivo K, Ramakrishnan C, Deisseroth K, Otte S, Stuber GD (2015) Visualizing hypothalamic network dynamics for appetitive and consummatory behaviors. Cell 160:516-527. CrossRef Medline

Jonaidi H, Noori Z (2012) Neuropeptide Y-induced feeding is dependent on GABAA receptors in neonatal chicks. J Comp Physiol A Neuroethol Sens Neural Behav Physiol 198:827-832. CrossRef Medline

Kalra SP, Kalra PS (2004) NPY and cohorts in regulating appetite, obesity and metabolic syndrome: beneficial effects of gene therapy. Neuropeptides 38:201-211. CrossRef Medline

Kalra SP, Dube MG, Pu S, Xu B, Horvath TL, Kalra PS (1999) Interacting appetite-regulating pathways in the hypothalamic regulation of body weight. Endocr Rev 20:68-100. CrossRef Medline

Kalsbeek A, Foppen E, Schalij I, Van Heijningen C, van der Vliet J, Fliers E, Buijs RM (2008) Circadian control of the daily plasma glucose rhythm: an interplay of GABA and glutamate. PLoS One 3:e3194. CrossRef Medline

Kong D, Tong Q, Ye C, Koda S, Fuller PM, Krashes MJ, Vong L, Ray RS, Olson DP, Lowell BB (2012) GABAergic RIP-Cre neurons in the arcuate nucleus selectively regulate energy expenditure. Cell 151:645-657. CrossRef Medline

Krashes MJ, Koda S, Ye C, Rogan SC, Adams AC, Cusher DS, Maratos-Flier E, Roth BL, Lowell BB (2011) Rapid, reversible activation of AgRP neurons drives feeding behavior in mice. J Clin Invest 121:1424-1428. CrossRef Medline

Krashes MJ, Shah BP, Koda S, Lowell BB (2013) Rapid versus delayed stimulation of feeding by the endogenously released AgRP neuron mediators GABA, NPY, and AgRP. Cell Metab 18:588-595. CrossRef Medline

Lee DA, Blackshaw S (2014) Feed your head: neurodevelopmental control of feeding and metabolism. Annu Rev Physiol 76:197-223. CrossRef Medline

Lee SW, Stanley BG (2005) NMDA receptors mediate feeding elicited by neuropeptide $\mathrm{Y}$ in the lateral and perifornical hypothalamus. Brain Res 1063:1-8. CrossRef Medline

Leibowitz SF (1991) Brain neuropeptide Y: an integrator of endocrine, metabolic and behavioral processes. Brain Res Bull 27:333-337. CrossRef Medline

Leibowitz SF, Sepiashvili K, Akabayashi A, Karatayev O, Davydova Z, Alexander JT, Wang J, Chang GQ (2005) Function of neuropeptide Y and agouti-related protein at weaning: relation to corticosterone, dietary carbohydrate and body weight. Brain Res 1036:180-191. CrossRef Medline

Leinninger GM, Jo YH, Leshan RL, Louis GW, Yang H, Barrera JG, Wilson H, Opland DM, Faouzi MA, Gong Y, Jones JC, Rhodes CJ, Chua S Jr, Diano S, Horvath TL, Seeley RJ, Becker JB, Münzberg H, Myers MG Jr (2009) Leptin acts via leptin receptor-expressing lateral hypothalamic neurons to modulate the mesolimbic dopamine system and suppress feeding. Cell Metab 10:89-98. CrossRef Medline

Lin S, Boey D, Herzog H (2004) NPY and Y receptors: lessons from transgenic and knockout models. Neuropeptides 38:189-200. CrossRef Medline

Liu T, Wang Q, Berglund ED, Tong Q (2012) Action of neurotransmitter: a key to unlock the AgRP neuron feeding circuit. Front Neurosci 6:200. CrossRef Medline

Low MJ, Otero-Corchon V, Parlow AF, Ramirez JL, Kumar U, Patel YC, Rubinstein M (2001) Somatostatin is required for masculinization of growth hormone-regulated hepatic gene expression but not of somatic growth. J Clin Invest 107:1571-1580. CrossRef Medline

Madisen L, Zwingman TA, Sunkin SM, Oh SW, Zariwala HA, Gu H, Ng LL, Palmiter RD, Hawrylycz MJ, Jones AR, Lein ES, Zeng H (2010) A robust and high-throughput Cre reporting and characterization system for the whole mouse brain. Nat Neurosci 13:133-140. CrossRef Medline

Melnick I, Pronchuk N, Cowley MA, Grove KL, Colmers WF (2007) Developmental switch in neuropeptide $\mathrm{Y}$ and melanocortin effects in the paraventricular nucleus of the hypothalamus. Neuron 56:1103-1115. CrossRef Medline

Misra M, Klibanski A (2014) Endocrine consequences of anorexia nervosa. Lancet Diabetes Endocrinol 2:581-592. CrossRef Medline

Morton GJ, Meek TH, Schwartz MW (2014) Neurobiology of food intake in health and disease. Nat Rev Neurosci 15:367-378. CrossRef Medline

Münzberg H, Jobst EE, Bates SH, Jones J, Villanueva E, Leshan R, Björnholm M, Elmquist J, Sleeman M, Cowley MA, Myers MG Jr (2007) Appropriate inhibition of orexigenic hypothalamic arcuate nucleus neurons independently of leptin receptor/STAT3 signaling. J Neurosci 27:69-74. CrossRef Medline

Pu S, Jain MR, Horvath TL, Diano S, Kalra PS, Kalra SP (1999) Interactions between neuropeptide $Y$ and gamma-aminobutyric acid in stimulation of feeding: a morphological and pharmacological analysis. Endocrinology 140:933-940. CrossRef Medline

Radley JJ, Gosselink KL, Sawchenko PE (2009) A discrete GABAergic relay mediates medial prefrontal cortical inhibition of the neuroendocrine stress response. J Neurosci 29:7330-7340. CrossRef Medline

Rocha ML, Fernandes PP, Lotufo BM, Manhães AC, Barradas PC, Tenorio F (2013) Undernutrition during early life alters neuropeptide Y distribution along the arcuate/paraventricular pathway. Neuroscience 256:379391. CrossRef Medline

Sheng G, Chang GQ, Lin JY, Yu ZX, Fang ZH, Rong J, Lipton SA, Li SH, Tong G, Leibowitz SF, Li XJ (2006) Hypothalamic huntingtin-associated protein 1 as a mediator of feeding behavior. Nat Med 12:526-533. CrossRef Medline

Sindelar DK, Palmiter RD, Woods SC, Schwartz MW (2005) Attenuated feeding responses to circadian and palatability cues in mice lacking neuropeptide Y. Peptides 26:2597-2602. CrossRef Medline

Song J, Xu Y, Hu X, Choi B, Tong Q (2010) Brain expression of Cre recombinase driven by pancreas-specific promoters. Genesis 48:628-634. CrossRef Medline

Stanley BG, Leibowitz SF (1984) Neuropeptide Y: stimulation of feeding and drinking by injection into the paraventricular nucleus. Life Sci 35: 2635-2642. CrossRef Medline

Stanley BG, Chin AS, Leibowitz SF (1985) Feeding and drinking elicited by central injection of neuropeptide Y: evidence for a hypothalamic site(s) of action. Brain Res Bull 14:521-524. CrossRef Medline 
Stanley BG, Magdalin W, Seirafi A, Thomas WJ, Leibowitz SF (1993a) The perifornical area: the major focus of (a) patchily distributed hypothalamic neuropeptide Y-sensitive feeding system(s). Brain Res 604:304-317. CrossRef Medline

Stanley BG, Willett VL 3rd, Donias HW, Ha LH, Spears LC (1993b) The lateral hypothalamus: a primary site mediating excitatory amino acidelicited eating. Brain Res 630:41-49. CrossRef Medline

Takahashi KA, Cone RD (2005) Fasting induces a large, leptin-dependent increase in the intrinsic action potential frequency of orexigenic arcuate nucleus neuropeptide Y/Agouti-related protein neurons. Endocrinology 146:1043-1047. CrossRef Medline

Thorsell A, Heilig M (2002) Diverse functions of neuropeptide Y revealed using genetically modified animals. Neuropeptides 36:182-193. CrossRef Medline

Tiesjema B, Adan RA, Luijendijk MC, Kalsbeek A, la Fleur SE (2007) Differential effects of recombinant adeno-associated virus-mediated neuropeptide $\mathrm{Y}$ overexpression in the hypothalamic paraventricular nucleus and lateral hypothalamus on feeding behavior. J Neurosci 27:14139-14146. CrossRef Medline

Tong Q, Ye C, McCrimmon RJ, Dhillon H, Choi B, Kramer MD, Yu J, Yang Z, Christiansen LM, Lee CE, Choi CS, Zigman JM, Shulman GI, Sherwin RS, Elmquist JK, Lowell BB (2007) Synaptic glutamate release by ventromedial hypothalamic neurons is part of the neurocircuitry that prevents hypoglycemia. Cell Metab 5:383-393. CrossRef Medline

Tong Q, Ye CP, Jones JE, Elmquist JK, Lowell BB (2008) Synaptic release of GABA by AgRP neurons is required for normal regulation of energy balance. Nat Neurosci 11:998-1000. CrossRef Medline

van de Wall E, Leshan R, Xu AW, Balthasar N, Coppari R, Liu SM, Jo YH, MacKenzie RG, Allison DB, Dun NJ, Elmquist J, Lowell BB, Barsh GS, de Luca C, Myers MG Jr, Schwartz GJ, Chua SC Jr (2008) Collective and individual functions of leptin receptor modulated neurons controlling metabolism and ingestion. Endocrinology 149:1773-1785. CrossRef Medline

Vong L, Ye C, Yang Z, Choi B, Chua S Jr, Lowell BB (2011) Leptin action on GABAergic neurons prevents obesity and reduces inhibitory tone to POMC neurons. Neuron 71:142-154. CrossRef Medline

Wang F, Flanagan J, Su N, Wang LC, Bui S, Nielson A, Wu X, Vo HT, Ma XJ,
Luo Y (2012) RNAscope: a novel in situ RNA analysis platform for formalin-fixed, paraffin-embedded tissues. J Mol Diagn 14:22-29. CrossRef Medline

Wicksteed B, Brissova M, Yan W, Opland DM, Plank JL, Reinert RB, Dickson LM, Tamarina NA, Philipson LH, Shostak A, Bernal-Mizrachi E, Elghazi L, Roe MW, Labosky PA, Myers MG Jr, Gannon M, Powers AC, Dempsey PJ (2010) Conditional gene targeting in mouse pancreatic SS-cells: analysis of ectopic Cre transgene expression in the brain. Diabetes 59:30903098. CrossRef Medline

Wu Q, Boyle MP, Palmiter RD (2009) Loss of GABAergic signaling by AgRP neurons to the parabrachial nucleus leads to starvation. Cell 137:12251234. CrossRef Medline

Wu Z, Kim ER, Sun H, Xu Y, Mangieri LR, Li DP, Pan HL, Xu Y, Arenkiel BR, Tong Q (2015) GABAergic projections from lateral hypothalamus to paraventricular hypothalamic nucleus promote feeding. J Neurosci 35: 3312-3318. CrossRef Medline

Xu AW, Kaelin CB, Morton GJ, Ogimoto K, Stanhope K, Graham J, Baskin DG, Havel P, Schwartz MW, Barsh GS (2005) Effects of hypothalamic neurodegeneration on energy balance. PLoS Biol 3:e415. CrossRef Medline

Xu Y, Tong Q (2011) Expanding neurotransmitters in the hypothalamic neurocircuitry for energy balance regulation. Protein Cell 2:800-813. CrossRef Medline

Xu Y, O’Brien WG 3rd, Lee CC, Myers MG Jr, Tong Q (2012) Role of GABA release from leptin receptor-expressing neurons in body weight regulation. Endocrinology 153:2223-2233. CrossRef Medline

Xu Y, Wu Z, Sun H, Zhu Y, Kim ER, Lowell BB, Arenkiel BR, Xu Y, Tong Q (2013) Glutamate mediates the function of melanocortin receptor 4 on Sim1 neurons in body weight regulation. Cell Metab 18:860-870. CrossRef Medline

Xu Y, Kim ER, Fan S, Xia Y, Xu Y, Huang C, Tong Q (2014) Profound and rapid reduction in body temperature induced by the melanocortin receptor agonists. Biochem Biophys Res Commun 451:184-189. CrossRef Medline

Yang L, Scott KA, Hyun J, Tamashiro KL, Tray N, Moran TH, Bi S (2009) Role of dorsomedial hypothalamic neuropeptide $\mathrm{Y}$ in modulating food intake and energy balance. J Neurosci 29:179-190. CrossRef Medline 